\title{
A Study on the Relationship between Body Composition Analysis and CBC in University Students
}

\author{
Yoon-kyung Jo ${ }^{1}$, Joon Yoon $^{2}$, Young-KuK Cho ${ }^{3}$, Hyun-Ho Sung ${ }^{1}$ \\ ${ }^{1}$ Department of Clinical Laboratory Science, Dongnam Health University, Suwon 16328, Korea \\ ${ }^{2}$ Department of Radiologic Technology, Dongnam Health University, Suwon 16328, Korea \\ ${ }^{3}$ Department of Medical Laboratory Science, Seoyeong University, Gwangju 61268, Korea
}

\section{대학생의 체성분분석과 혈구산정검사의 관계연구}

\author{
조윤경 ${ }^{1},{\text { 윤 } \text { 준 }^{2}, \text { 조영국 }}^{3}$, 성현호 $^{1}$ \\ ${ }^{1}$ 동남보건대학교 임상병리과, ${ }^{2}$ 동남보건대학교 방사선과, ${ }^{3}$ 서영대학교 임상병리과
}

Key words: Body composition analysis, Complete blood cell count, University student

This is an Open Access article distributed under the terms of the Creative Commons Attribution Non-Commercial Licens (http://creativecommons.org/licenses/by-nc/4.0) which permits unrestricted non-commercial use, distribution, and reproduction in any medium, provided the original work is properly cited.

Copyright (C) 2016 The Korean Society for Clinical Laboratory Science. All rights reserved.

\begin{abstract}
The tendency of students to become adults in the future to improve the country's public health policy and to determine the socio-economic development of the research is very important. The objectives of this study were to examine the changes in body weight, body mass index (BMI), body composition, and complete blood cell count in a group of male and female university students. Among the body compositions, height, weight, BMI, muscle volume, basal metabolic rate, red blood cells, hemoglobin, and hematocrit showed a correlation between the amount shown both had statistical significance $(p<0.01)$. In particular, platelets showed a rather different result from fat and body fat percentage, and were positively correlated with waist-hip ratio points $(p<0.01)$. This study may be useful as it provides the basic data necessary for students of healthcare. Therefore, developing a sustainable management system of healthcare on a national level for

university students is very important.
\end{abstract}

\author{
Corresponding author: Hyun-Ho Sung \\ Department of Clinical Laboratory Science, \\ Dongnam Health University, 50 \\ Cheoncheon-ro, 74-Gil Jangan-gu, \\ Suwon 16328 , Korea \\ Tel: 82-31-249-6414 \\ Fax: 82-31-249-6410 \\ E-mail:wantyou7@dongnam.ac.kr
}

Received: August 1, 2016

Revised $1^{\text {st: }}$ : August 21, 2016

Revised 2 ${ }^{\text {nd }}$ : August 25, 2016

Revised $3^{\text {rd }}$ : August 26, 2016

Accepted: August 26, 2016

\section{서 론}

대학생들은 일반적으로 사망률이나 질병의 이환율이 낮고 체력 적으로 건강한 생애주기에 해당하는 집단으로 알려져 있지만, 잘못 된 건강습관이나 부적절한 스트레스의 노출로 인하여 건강상태뿐 만 아니라 향후 성인이 되었을 때 건강 수준에도 영향을 미칠 수 있 다[1]. 출생했을 때의 저체중은 성인이 되었을 때 심혈관 질환 및 당 뇨의 위험성과 관련성이 있으며, 체성분 검사는 이들이 성장하면서 체지방 양을 증가시키는 것으로 이러한 질환을 관리할 수 있는 잠 재적인 매개체가 될 수 있다[2]. 대학생들은 불규칙적인 식사와 간
식의 비중이 높고, 음주율과 흡연율이 높으며, 저체중에서 비만까 지 다양한 체중 분포를 보이는 집단으로 생활습관에 따른 많은 건 강문제를 가지고 있다[3,4]. 현재 미국에서는 정부차원에서 대학생 들의 건강 관리의 중요성과 건강증진을 위하여 관련 지식을 제공하 고 대학생들의 생활양식을 변화시키려는 조직적인 발전을 도모하 고 있다[5]. 그러나 우리나라에서는 아직까지 건강증진에 관련된 노력이 중 노년층에 중점을 이루고 있어 대학생은 그 대상에서 벗 어나고 있는 상황이다[6,7].

우리나라는 1997년 12월 31일 국민건강보험법을 근거로 건강 검진을 무료로 실시하고 있으며, 2008년 3월 21일 건강검진기본 
법이 재정되어 일반건강검진, 암검진, 영유아건강검진을 실시하고 있다. 건강검진 기본항목으로 신장, 체중, 혈압, 혈색소, 공복혈당, 총콜레스테롤, 고밀도지단백콜레스테롤, 중성지방, 저밀도지단백 콜레스테롤, 3 종간기능검사, 혈청크레아틴, 소변단백검사 결과를 수집하여 고혈압, 비만, 빈혈, 당뇨병, 이상지혈증, 간장질환, 신장 질환 등의 이상 유무를 평가하고 있다[8]. 또한초·중·고 학생들 은 학교보건법과 학교건강검사규칙에 근거하여 매년 같은 검사항 목으로 학생건강검사를 실시하고 있다. 그러나 현재까지 대학생들 은 법적인 건강관리 관련법령의 부재로 인하여 건강검진을 받고 있 지 않은 실정이다. 이러한 배경으로 대학생들의 건강관리에 관련된 연구가 부족하며, 특히 임상병리학적 검사결과의 접근이 부족하 다. 따라서 본 논문은 체성분 분석과 기본혈액검사인 혈구산정검사 (complete blood cell count, $\mathrm{CBC}$ )를 의료적 진단을 제외하고 직 접 실험을 진행하여 얻은 데이터를 중심으로 비교하여 건강관리의 사각지대로 인하여 취업 전 채용검진 등에서 불이익을 받는 등, 개 인과 사회적 문제를 예방하고 장기적인 대학생을 대상으로 하는 기 초 연구 자료 제공을 목적으로 하였다.

\section{재료 및 방법}

\section{1. 연구대상}

본 연구는 연구의 목적을 설명하고 연구방법 및 연구참여기간, 부작용 위험요소, 개인정보와 비밀보장에 대한 내용을 교내 공지게 시판을 통해 2015년 8월 한 달간 연구대상자를 모집하여 학생들에 게 모두 서면으로 동의를 얻어 연구를 수행하였다. 2015년 9월 15 일부터 16 일까지 경기도 수원시에 위치한 D 대학교 재학생들을 대 상으로 체성분 분석과 혈액산정검사를 실시하였다. 대상자는 전체 57 명 중 남학생이 27명, 여학생이 30명이었다.

\section{2. 체성분 분석}

체성분 분석은 생체전기저항분석법을 이용한 체성분 분석은 Inbody 770 (Biospace Co., Seoul, Korea) 장비를 사용하여 측정 하였다. 측정된 검사항목으로는 체질량 지수(body mass index, $\mathrm{BMI}$, 골격근량(skeletal muscle mass, SMM), 체지방량(body fat mass, BFM), 총 체수분양(total body water, TBW), 체지방률 (percent body fat, $\mathrm{PBF}$ ), 카프만 지수 계산법의 허리와 엉덩이의 비율(waist hip ratio, WHR), 기초대사량(basal metabolic rate, $\mathrm{BMR})$ 이다

\section{3. 혈구산정검사}

혈액 채취는 연구대상자의 공복상태를 확인 후 채혈하였다. 채
혈부위는 팔오금중간정맥(median cubital vein)에서 일회용 진공 채혈세트(Becton Dickinson, Franklin Lakes, NJ, USA)를 사용하 여 항응고제가 포함된 진공 채혈관(ethylenediaminetetraacetic acid, EDTA)에 $3 \mathrm{~mL}$ 를 1회 채혈하였다. 혈구산정검사는 $\mathrm{LABGEO}$ HC10 (Samsung Medison Co., Suwon, Korea)를 사용하였다. 혈 구산정검사(complete blood cell count, $\mathrm{CBC}$ ) 항목의 구성내용 은 백혈구 수(white blood cell, WBC), 백혈구 감별계산(WBC differential count), 적혈구수(red blood cell, RBC), 적혈구용적 률(hematocrit, Hct), 혈색소 농도(hemoglobin, $\mathrm{Hb}$ ), 평균적혈구 용적(mean corpuscular volume, $\mathrm{MCV}$ ), 평균 적혈구혈색소 (mean corpuscular hemoglobin, $\mathrm{MCH}$ ), 평균적혈구혈색소농도 (mean corpuscular hemoglobin concentration, $\mathrm{MCHC}$ ), 적혈 구분포지수(red cell distribution width, $\mathrm{RDW}$ ), 혈소판 수 (platelet, PLT)를 분석하였다.

\section{4. 통계분석}

통계 분석은 SPSS 버전 21.0 프로그램(SPSS Inc., Chicago, Illinois, USA)을 이용하였다. 연구대상자의 연속 변수는 모두 평균 \pm 표준편차로 표기하였다. 대상자의 일반적 특성을 분석하기 위해 빈도분석을 실시하였고, 성별에 따른 결과 차이 분석을 위하여 독 립 $t$-검정을 사용하였다. 신체조성결과와 혈구산정검사 결과의 관계를 통계적으로 입증하기 위하여 Pearson상관분석을 실시하 였다.

\section{결 과}

\section{1. 대상자의 일반적 특성}

연구 대상자는 평균연령은 $21.95 \pm 2.67$ 세였다. 그 중 남학생은 27 명(48.4\%) 여학생은 30 명(51.6\%)이었다. 성별에 따른 연령차이 는 통계적으로 유의한 차이가 없어 동일한 집단으로 나타났고, 신 장과 체중은 남학생이 여학생보다 높게 나타났으며 $(p<0.01)$, 체 질량지수의 차이는 남학생이 여학생보다 높게 나타났다 $(p<0.05)$ (Table 1).

\section{2. 성별에 따른 체성분 변화}

골격근량과 총 체수분양, 기초대사량에서 남학생이 여학생보다 전체적으로 높게 나타났으며 통계적으로 유의하였다 $(p<0.01)$, 체 지방률은 여성이 남성보다 높게 나타났으며, 통계적으로 유의하였 다 $(p<0.01)$. 체지방양은 여성이 남성보다 다소 높은 경향이 나타 났으며, 허리와 엉덩이의 비율은 차이가 없었다(Table 2). 
Table 1. General characteristics of subjects

\begin{tabular}{lcccc}
\hline Variable & Total & Male & Female & Flt \\
& $\mathrm{n}=57$ & $\mathrm{n}=27(48.4 \%)$ & $\mathrm{n}=30(51.6 \%)$ & $1.35 /-1.34$ \\
Age & $21.95 \pm 2.67$ & $22.44 \pm 2.61$ & $21.50 \pm 2.70$ & $2.84 /-5.01^{\star *}$ \\
Height $(\mathrm{cm})$ & $167.30 \pm 8.17$ & $172.07 \pm 8.17$ & $163.00 \pm 5.35$ & $10.39^{\star *} /-4.46^{\star *}$ \\
Weight $(\mathrm{kg})$ & $60.48 \pm 11.89$ & $67.01 \pm 13.76$ & $54.50 \pm 5.10$ & $4.54^{\star} /-2.58^{\star}$ \\
BMI $\left(\mathrm{kg} / \mathrm{m}^{2}\right)$ & $21.48 \pm 3.05$ & $22.53 \pm 3.79$ & $20.53 \pm 1.79$ & \\
\hline
\end{tabular}

${ }^{*} p<0.05,{ }^{* *} p<0.01$.

Abbreviation: BMI, body mass index.

Table 2. Results of body composition by gender

\begin{tabular}{lcccc}
\hline Variable & $\begin{array}{c}\text { Total } \\
\mathrm{n}=57\end{array}$ & $\begin{array}{c}\text { Male } \\
\mathrm{n}=27(48.4 \%)\end{array}$ & $\mathrm{n}=30(51.6 \%)$ & $\mathrm{Flt}$ \\
\hline SMM (kg) & $24.91 \pm 6.47$ & $29.76 \pm 6.27$ & $20.55 \pm 2.01$ & $16.79^{\star \star} /-7.28^{\star \star}$ \\
BFM (kg) & $15.21 \pm 5.80$ & $14.00 \pm 7.15$ & $16.30 \pm 4.06$ & $2.20 / 1.50$ \\
TBW (kg) & $33.16 \pm 7.73$ & $38.91 \pm 7.51$ & $27.98 \pm 2.50$ & $15.94^{\star *} /-7.20^{\star \star}$ \\
PBF (\%) & $25.35 \pm 7.74$ & $20.51 \pm 7.09$ & $29.64 \pm 5.49$ & $0.59 / 5.42^{\star \star}$ \\
WHR & $0.83 \pm 0.05$ & $0.84 \pm 0.55$ & $0.83 \pm 0.43$ & $1.65 /-0.54$ \\
BMR & $1347.79 \pm 227.45$ & $1516.44 \pm 221.70$ & $1196.00 \pm 74.25$ & $16.23^{\star \star} /-7.15^{\star \star}$ \\
\hline
\end{tabular}

${ }^{* *} p<0.01$.

Abbreviation: SMM, skeletal muscle mass; BFM, body fat mass; TBW, total body water; PBF, percent body fat; WHR, waist hip ratio, $\mathrm{BMR}$, basal metabolic rate.

Table 3. Results of CBC by gender

\begin{tabular}{|c|c|c|c|c|}
\hline Variable & $\begin{array}{l}\text { Total } \\
\mathrm{n}=57\end{array}$ & $\begin{array}{c}\text { Male } \\
\mathrm{n}=27(48.4 \%)\end{array}$ & $\begin{array}{c}\text { Female } \\
\mathrm{n}=30(51.6 \%)\end{array}$ & $F / t$ \\
\hline $\operatorname{WBC}\left(10^{3} / \mu \mathrm{L}\right)$ & $6.45 \pm 1.56$ & $6.59 \pm 1.70$ & $6.32 \pm 1.44$ & $0.58 /-0.65$ \\
\hline LYM (\%) & $30.13 \pm 5.37$ & $28.79 \pm 7.76$ & $31.33 \pm 7.93$ & $0.01 / 1.21$ \\
\hline MON (\%) & $5.37 \pm 2.13$ & $5.11 \pm 2.10$ & $5.61 \pm 2.17$ & $0.04 / 0.89$ \\
\hline GRA (\%) & $64.51 \pm 8.65$ & $66.11 \pm 8.64$ & $63.06 \pm 8.54$ & $0.07 /-1.33$ \\
\hline $\operatorname{RBC}\left(10^{6} / \mu \mathrm{L}\right)$ & $4.60 \pm 0.49$ & $4.94 \pm 0.44$ & $4.30 \pm 0.32$ & $0.47 /-6.23^{* *}$ \\
\hline $\mathrm{Hb}(\mathrm{g} / \mathrm{dL})$ & $13.88 \pm 1.80$ & $15.21 \pm 1.43$ & $12.68 \pm 1.13$ & $0.04 /-7.45^{\star \star}$ \\
\hline $\mathrm{HCT}(\%)$ & $37.62 \pm 4.62$ & $41.04 \pm 3.62$ & $34.54 \pm 2.96$ & $0.00 /-7.43^{\star *}$ \\
\hline MCV (fL) & $81.68 \pm 4.91$ & $83.19 \pm 3.10$ & $80.33 \pm 5.83$ & $7.73^{* *} /-2.43^{*}$ \\
\hline $\mathrm{MCH}(\mathrm{pg})$ & $30.16 \pm 2.15$ & $30.87 \pm 1.49$ & $29.52 \pm 2.46$ & $6.43^{\star} /-2.51^{*}$ \\
\hline $\mathrm{MCHC}(\mathrm{g} / \mathrm{dL})$ & $36.86 \pm 0.59$ & $37.04 \pm 0.55$ & $36.69 \pm 0.59$ & $0.07 /-2.33^{*}$ \\
\hline RDW (fL) & $14.99 \pm 1.16$ & $14.80 \pm 0.79$ & $15.16 \pm 1.41$ & $5.66^{*} / 1.21$ \\
\hline $\operatorname{PLT}\left(10^{3} / \mu \mathrm{L}\right)$ & $217.88 \pm 63.19$ & $205.63 \pm 41.25$ & $228.90 \pm 76.94$ & $4.74 / 1.44$ \\
\hline
\end{tabular}

${ }^{*} p<0.05,{ }^{* *} p<0.01$.

Abbreviation: CBC, complete blood cell count WBC, white blood cell; LYM, lymphocyte; MON, monocyte; GRA, granulocyte; RBC, red blood cell; Hb, hemoglobin; HCT, Hematocrit; MCV, mean corpuscular volume; MCH, mean corpuscular hemoglobin; MCHC, mean corpuscular hemoglobin concentration; RDW, red cell distribution width; PLT, platelet.

\section{3. 성별에 따른 $\mathrm{CBC}$ 의 변화}

성별에 따른 적혈구 수와 혈색소 그리고 적혈구용적률의 차이는 남학생이 여학생보다 높게 나타났으며, 통계적으로 유의한 차이를 나타내었다 $(p<0.01)$. 평균적혈구용적, 평균 적혈구혈색소, 평균 적혈구혈색소농도에서는 남학생이 여학생보다 전체적으로 높게 나타났으며, 통계적으로 유의한 차이를 보였다 $(p<0.05)$ (Table 3).

\section{4. 체성분과 혈구산정검사의 상관성}

신장과 체중 그리고 골격근양은 적혈구수와 혈색소 그리고 적혈 구용적률 등에서 양의 상관관계를 보였다 $(p<0.01)$. 체수분양과 체지방량 그리고 기초대사량은 적혈구수와 혈색소 그리고 적혈구 용적률 등에서 양의 상관관계를 보였다 $(p<0.01)$. 체중과 골격근 양 그리고 체수분 양은 평균적혈구용적률과 양의 상관관계를 보였 으며 $(p<0.05)$, 평균 적혈구 혈색소는 신장과 양의 상관성을 보였 
Table 4. Correlation of body composition and CBC results

\begin{tabular}{|c|c|c|c|c|c|c|c|c|c|}
\hline Variable & $\begin{array}{l}\text { Height } \\
(\mathrm{cm})\end{array}$ & $\begin{array}{l}\text { Weight } \\
(\mathrm{kg})\end{array}$ & $\begin{array}{c}\mathrm{BMI} \\
\left(\mathrm{kg} / \mathrm{m}^{2}\right)\end{array}$ & $\begin{array}{c}\text { SMM } \\
(\mathrm{kg})\end{array}$ & $\begin{array}{l}\text { BFM } \\
\text { (kg) }\end{array}$ & $\begin{array}{l}\text { TBW } \\
(\mathrm{kg})\end{array}$ & $\begin{array}{l}\text { PBF } \\
(\mathrm{kg})\end{array}$ & WHR & BMR \\
\hline $\mathrm{RBC}\left(10^{6} / \mu \mathrm{L}\right)$ & $0.410^{\star \star}$ & $0.438^{\star \star}$ & $0.320^{\star \star}$ & $0.550^{\star \star}$ & -0.079 & $0.540^{\star \star}$ & $-0.390^{\star \star}$ & 0.143 & $0.537^{\star \star}$ \\
\hline $\mathrm{Hb}(\mathrm{g} / \mathrm{dL})$ & $0.491^{\star \star}$ & $0.552^{\star \star}$ & $0.417^{\star *}$ & $0.663^{\star \star}$ & -0.055 & $0.656^{\star \star}$ & $-0.434^{\star \star}$ & 0.189 & $0.653^{\star \star}$ \\
\hline $\mathrm{HCT}(\%)$ & $0.484^{\star \star}$ & $0.536^{\star *}$ & $0.401^{\star \star}$ & $0.650^{\star *}$ & -0.062 & $0.642^{\star *}$ & $-0.432^{* *}$ & 0.190 & $0.639^{\text {** }}$ \\
\hline MCV (fL) & 0.232 & $0.278^{\star}$ & 0.217 & $0.308^{*}$ & 0.009 & $0.310^{\star}$ & $-0.169^{*}$ & 0.128 & 0.309 \\
\hline $\mathrm{MCH}(\mathrm{pg})$ & $0.290^{*}$ & $0.353^{\star \star}$ & 0.278 & $0.383^{\star \star}$ & 0.026 & $0.384^{\star \star}$ & -0.193 & 0.143 & 0.384 \\
\hline $\mathrm{MCHC}(\mathrm{g} / \mathrm{dL})$ & 0.246 & $0.332^{\star}$ & $0.280^{*}$ & $0.351^{\star *}$ & 0.047 & $0.348^{\star}$ & -0.167 & 0.104 & $0.349^{\star \star *}$ \\
\hline $\operatorname{PLT}\left(10^{3} / \mu \mathrm{L}\right)$ & -0.253 & -0.041 & 0.105 & -0.167 & $0.228^{\star \star}$ & -0.173 & $0.270^{\star \star}$ & $0.159^{\star \star}$ & -0.172 \\
\hline
\end{tabular}

${ }^{\star} p<0.05,{ }^{* \star} p<0.01$.

Abbreviation: 'See Table 1, 2, 3'.

으며 $(p<0.05)$, 체중과 골격근량 그리고 체수분량에서 양의 상관 관계를 보였다 $(p<0.01)$. 평균적혈구혈색소농도는 체중, 골격근 양, 기초대사량 사이에서 양의 상관성을 보였으며 $(p<0.01)$, 골격 근에 있어서도 통계적으로 유의한 상관성이 나타났다 $(p<0.01)$. 혈소판은 체지방양, 체지방률, 허리엉덩이비율에 대해 통계적으로 유의한 양의 상관성을 보였다 $(p<0.01)$ (Table 4).

\section{고 찰}

$\mathrm{CBC}$ 는 의사가 처방하는 가장 흔한 혈액검사 중 하나이다. $\mathrm{CBC}$ 분석정보들은 혈액질환을 않고 있는 환자에서 진찰과정 중 얻어지 는 의학정보와 함께 혈액 관련 증상을 초래한 원인질환의 병태생리 를 이해하고 정확한 진단을 할 수 있도록 도움을 준다[9]. 신체조성 과 철 대사 지수, 혈청 단백질, 혈장 콜레스테롤 간의 연관성이 있으 며, 만성 질환, 빈혈 및 영양 실조 등과 관련이 있다. 특히, 체중에 따 라 신장, 체질량지수, 피하 지방 두께, 지방을 제외한 근육 등의 무 게는 헤모글로빈, 적혈구 용적, 총 철 결합 용량과 상관관계가 있으 며, 체지방은 혈청 알부민 농도는 관련이 있고, 총 콜레스테롤 농도 는 직접적으로 체중과 체지방과 관련하여 비만과 관련성이 높아 역 학조사의 중요한 임상평가 요인으로 볼 수 있다[10-13]. 신체조성 중 BMI는 비만을 쉽게 구분할 수 있으나 BMI는 근육으로 인한 체중 증가를 구분하지 못하기 때문에, WHR은 복부 비만을 구분하는 사 용될 수 있으며, 최근 메타 분석에서 $\mathrm{BMI}$ 보다 WHR이 정확한 것으 로 보고하고 있다[14]. 세계보건기구(world health organization, $\mathrm{WHO}$ )에 따르면, 비만은 이제 전세계적인 문제이며, 세계 인구의 $65 \%$ 가 비만으로 사망률이 높다고 보고하고 있다[15]. 비만은 CBC 검사결과에 영향을 끼친다. 비만은 헤모글로빈 수준과 백혈구 수치 를 증가시킨다[16-18]. 일본의 한 연구에서는 고혈압이 호중구의 수치의 다양한 변화와 관련이 있는 것으로 보고하였다[19]. 국내 논 문에서는 허리둘레, 체질량지수와 심장구조 및 기능의 상관성을 검 증한 결과 허리둘레와 체질량지수 모두 심장구조와 이완기 기능 간
에 상관성이 있는 것으로 나타났다[20]. 선행연구 결과를 살펴보면 본 연구 결과와 모두 동일한 결과로 나타났다. 특히 신장과 체중, 체 질량지수 그리고 골격근 양과 기초대사량이 증가될수록 적혈구 수, 혈색소, 적혈구용적률에서 통계적으로 유의한 양의 상관성을 보였 다 $(p<0.01)$. 체지방 양의 증가는 백혈구 수 및 C-반응성 단백시험 (C-reactive protein, $\mathrm{CRP}$ )와 상관성이 높으며, 안지오텐신 II (angiotensin II)와 관련성이 높은 것으로 보고하고 있다[21]. 그러 나 본 연구에서는 백혈구와 호중구 사이의 관계는 유의성이 없게 나타났으며, 향후 체지방 양과 $\mathrm{WBC}$ 그리고 $\mathrm{CRP}$ 의 관계도 추가 연 구가 필요할 것으로 사료된다. 또한 이번 연구에서는 혈소판이 체 지방량과 체지방률, 허리와 엉덩이 비율에서 통계적으로 양의 상관 관계를 보였는데 $(p<0.01)$, 이는 $\mathrm{Kim}$ 등[22]이 보고한 고령 여성 에게서 공복감 인지수준과 비만 변인의 관련성 연구에서 비만 여성 에게서 혈소판수치가 유의하게 높은 결과를 보인 부분이 본 연구 결과와일치하였다. 또한 $\mathrm{BMI}$ 와 $\mathrm{WC}$ 가 높은 비만환자와 정상인과 의 비교에서 유의하게 높은 결과를 보이는 부분이 혈전 위험을 기 초로 한 중요 메커니즘을 의미하는 것으로 본 연구 결과와 일치하 는 것으로 나타났다[23]. 또한, 말레이시아 청소년을 대상으로 연 구한 결과에서 체질량지수와 허리둘레와 체지방률이 증가할 경우 심혈관 질환 발병위험이 증가한다고 하였다[24]. 또한, 아동의 타 액에서 측정한 코티솔(salivary latent trait cortisol, sLTC)수준은 BMI, WHR, Fat (\%)와상관관계가 있다고 하였다[25]. 최근 저 탄수 화물 섭취를 통해 체지방량이 감소된다는 보고가 있었다[26]. 대학 생을 대상으로 신체활동에 따른 신체조성과 마이오카인 (myokines) 중 인터루킨 6 (interleukin-6, IL-6), 인터루킨 8 (interleukin-8, IL-8), 인터루킨 15 (interleukin-15, IL-15)의 분 석결과, IL-6, IL-8, IL-15은 신체조성과 운동량과의 상당한 차이 를 분석한 연구도 있었다[27]. 미국 대학생을 대상으로 인종에 따른 체중과 심혈관계질환의 관련성으로 인종에 따른 차이, 신체활동과 같은 건강증진행위에 따라 다르다는 연구 결과도 있었다[28]. 이를 통해 체지방량과 스트레스인자, 면역인자, 심혈관계 인자들의 연 
관성이 있음을 알 수 있었으며 이에 대한 기전 연구는 향후 이루어 져야 할 것으로 보인다

한편, 최근 고령화에 대한 문제가 많이 제기되고 있다. 2030년에 는 전체인구의 $60.9 \%$ 가 40 세 이상인구에 속할 것이라고 한다. 검 진기관에 따라 다양한 건강검진이 존재하는데 보건복지부의 건강 검진실시기준에 서는 검진의 종류를 일반건강검진, 암검진, 생애 전환기검진, 영 유아검진으로 분류하고 있다. 특히 일반건강검진 의 경우 만 41 세부터 64 세의 국민에게 적용된다. 이러한 배경으로 앞선 연구들에서 학생들의 경향 연구는 논리적으로 매우 필요하다. 초-중·고 학생들은 학교보건법과 학교건강검사규칙에 근거하 여 매년 학생건강검사를 실시하고 있지만 성인 초기에 해당되는 대 학생들은 건강검진과 관련된 규정이 없어 국가적 건강관리의 사각 지대에 놓여있다. 특히, 대학생은 성인초기에 해당하며, 상대적으 로 생활양식의 수정 가능성이 크고 바람직한 건강습관을 형성할 수 있는 중요한 시기이기 때문에 대학생 때 형성된 바람직한 건강증진 행위는 평생 동안의 건강관리에 있어서 매우 중요한 요인이 된다. 그러나 대학생들은 건강검진관련 법적 근거가 없어 건강검진을 시 행하지 않고 있다. 우리나라의 대학생 문화는 학생들의 신체적, 정 신적 건강을 위협하는 다양한 위해 요소를 포함하고 있다. 즉, 대학 생들은 음주나 흡연 및 불규칙한 식사 습관뿐만 아니라 수면부족 등의 신체적 건강의 위협요소를 가지고 있다. 학교에 따라 기숙이 나 자취로 인해 영양 불균형과 운동부족이 초래되고 무절제 한 생 활양식을 가질 위험성 또한 증가한다. 더불어 가속화되는 경쟁적 사회로 인하여 미래에 대한 진로와 인간관계 등에서 스트레스와 우 울감이 증가할 수 있고, 자존감이 저하될 수 있어 심리적, 사회적인 부분에서 다양한 건강 위협요소에 노출되고 있다. 본 연구는 몇 가 지 제한점이 있다. 첫째, 대학생을 대상으로 직접 실험을 진행한 사 항으로 표본수가 부족한 부분이다. 둘째로 대규모의 전향적 선행연 구 자료가 없어 차이를 분석할 수 없다는 점이다. 따라서 향후 다양 한 임상병리학적인 접근으로 대규모의 융합적인 연구가 필요할 것 으로 사료된다. 또한, 대학생들의 건강관리는 국가적으로 매우 중 요한 부분을 차지할 수 있으며, 지속적인 관리체계 구축과 그에 따 른 제도적 마련이 필요할 것이며, 그에 따른 적절한 데이터의 활용 으로 국민건강증진에 기여해야 할 것으로 사료된다.

\section{요 약}

국가의 공중 보건 정책을 개선하고 사회 경제적 발전을 결정하 기 위하여 미래에 성인이 될 학생의 경향 연구는 매우 중요한 일이 다. 본 논문은 남녀 대학생의 체중과 체질량지수 그리고 신체조성 과 $\mathrm{CBC}$ 결과와 관계를 분석하는데 목적이 있다. 연구 결과, 신체조
성 중에서 신장과 체중, 체질량지수 그리고 골격근 양, 기초대사량 과 적혈구 수와 혈색소 그리고 적혈구용적률 등에서 양에 상관관계 를 나타내었고 모두 통계적인 유의성이 있었다 $(p<0.01)$. 특히, 혈 소판은 체지방량과 체지방률 그리고 허리와 엉덩이 비율에서 양의 상관관계로 나타났다 $(p<0.01)$. 이러한 연구결과는 대학생들의 건 강관리에 필요한 기초자료로 의미가 있다. 따라서 대학생의 건강관 리와 관련된 다량의 연구는 전략적으로 반드시 필요하다. 따라서 대학생들의 건강관리는 국가적으로 매우 중요한 부분을 차지할 수 있으며, 지속적인 관리체계 구축과 그에 따른 제도적 마련이 필요 하다고 사료된다.

\section{Acknowledgements: None}

Funding: This study was financially supported by Dongnam Health University.

Conflict of interest: None

\section{References}

1. Han KS. Self efficacy, health promoting behaviors, and symptoms of stress among university students. J Korean Acad Nurs. 2005;35(3):585-592.

2. Kofler T, Bossard M, Aeschbacher S, Tabord A, Repilado R, Javier $\mathrm{F}$, et al. The interrelationships of birthweight, inflammation and body composition in healthy adults. Eur J Clin Invest. 2016;46(4):342-348.

3. Jwa HJ, Chae IS. Body shape satisfaction, nutrition knowledge, dietary habits, and weight control attitude of korean high school students. Korean J Food Cult. 2008;23(6):820-833.

4. Soh HK, Lee EJ, Choi BS. The development of nutrition education program for improvement of body perception of middle school girls (I). The analysis of problems according to the body perception of middle school girls. Korean J Food Cult. 2008; 23(3):403-409.

5. American College Health Association, Healthy campus 2013 [cited 2016 August 20]. Available from: http://www.achancha.org/docs/ACHANCHA-II_ReferenceGroup_ExecutiveSummary_Spring2013.pdf.

6. Kim YB. An analysis on the change of health status, health behavior, and influencing factors among american college and university students. Korean J Health Educ Promot. 2010;27(4): 153-163.

7. Kim YB, Park CM, Kim HH, Han CH. Health behavior and utilization of university health clinics. J Korean Soc Sch Health. 2010;13(6):31-43.

8. Kim YM, Park JH, Kim WJ. Analysis of utilization characteristics, health behaviors and health management level of participants in private health examination in a general hospital. J Korea Acad Industr Coop Soc. 2013;14(1):301-311.

9. Park SK. An interpretation on abnormal finding of CBC. Korean 
J Med. 2010;78(5):531-539.

10. Micozzi, MS, Albanes D, Stevens RG. Relation of body size and composition to clinical biochemical and hematologic indices in US men and women. Am J Clin Nutr. 1989;50(6):1276-1281.

11. Choi KM, Lee J, Kim YH, Kim KB, Kim DL, Kim SG, et al. Relation between insulin resistance and hematological parameters in elderly Koreans-Southwest Seoul (SWS) study. Diabetes Res Clin Pract. 2003;60(3):205-212.

12. Shim WS, Kim HJ, Kang ES, Ahn CW, Lim SK, Lee HC, et al. The association of total and differential white blood cell count with metabolic syndrome in type 2 diabetic patients. Diabetes Res Clin Pract. 2006;73(3):284-291.

13. Kim DJ, Noh JH, Lee BW, Choi YH, Chung JH, Min YK, et al. The associations of total and differential white blood cell counts with obesity, hypertension, dyslipidemia and glucose intolerance in a Korean population. J Korean Med Sci. 2008;23(2): 193-198.

14. Grundy SM, Cleeman JI, Daniels SR, Donato KA, Eckel RH, Franklin BA, et al. Diagnosis and management of the metabolic syndrome: An american heart association/national heart, lung, and blood institute scientific statement. Circulation. 2005; 112(17):2735-2752.

15. WHO. Obesity and overweight. Fact Sheet $\mathrm{N}^{\circ} 311$. World Health Organization. Updated March 2013 [cited 2016 August 20]. Available from: http://www.who.int/mediacentre/factsheets/fs311/en/.

16. Micozzi MS, Albanes D, Stevens RG. Relation of body size and composition to clinical biochemical and hematologic indices in US men and women. Am J Clin Nutr. 1989;50(6):1276-1281.

17. Ungtrongchitr R, Pongpaew P, Phonrat B, Tribunyatkul S, Viroonudomphol D, Supawan, V, et al. Leptin concentration in relation to body mass index (BMI) and hematological measurements in Thai obese and overweight subjects. Southeast Asian J Trop Med Public Health. 2000;31:787-794.

18. Al-Hashem FH. Is it necessary to consider obesity when constructing norms for hemoglobin or when screening for anemia using hemoglobin levels? Saudi Med J. 2007;28(1):41-45.

19. Tatsukawa Y, Hsu WL, Yamada M, Cologne JB, Suzuki G, Yamamoto H, et al. White blood cell count, especially neu- trophil count, as a predictor of hypertension in a Japanese population. Hypertens Res. 2008;31(7):1391-1397.

20. Shin KA, Hong SB. Difference of the cardiac structure and function depending on obesity level of healthy adults. J Exp Biomed Sci. 2011;17(2):141-149.

21. Majid HA, Amiri M, Azmi NM, Su TT, Jalaludin MY, Al-Sadat N. Physical activity, body composition and lipids changes in adolescents: analysis from the MyHeART Study. Sci Rep. 2016; 28(6):30544. doi: 10.1038/srep30544

22. Kim JH, Kim DJ, Park SH. The study on the relationship between hunger recognition level and obesity variable of elderly women. The Korean Journal of Physical Education. 2015;54(6): 475-483.

23. Minervino D, Gumiero D, Nicolazzi MA, Carnicelli A, Fuorlo M, Guidone C, et al. Leukocyte activation in obese patients: effect of bariatric surgery. Medicine. 2015;94(40):e1382. doi: 10.1097/ MD.0000000000001382.

24. Farhangi MA, Keshavarz SA, Eshraghian M, Ostadrahimi A, Saboor-Yaraghi AA. White blood cell count in women: relation to inflammatory biomarkers, haematological profiles, visceral adiposity, and other cardiovascular risk factors. J Health Popul Nutr. 2013;31(1):58-64.

25. Yeung EW, Place R, Gordish-Dressman H, Visich P, Hoffman E, Walker SO, et al. Salivary latent trait cortisol (LTC): Relation to lipids, blood pressure, and body composition in middle childhood. Psychoneuroendocrinology. 2016;71:110-118.

26. Hashimoto Y, Fukuda T, Oyabu C, Tanaka M, Asano M, Yamazaki M, et al. Impact of low-carbohydrate diet on body composition: meta-analysis of randomized controlled studies. Obes Rev. 2016;17(6):499-509.

27. Yeo NH, Woo J, Shin KO, Park JY, Kang S. The effects of different exercise intensity on myokine and angiogenesis factors. J Sport Med. 2012;52(4):448-454.

28. Price AA, Whitt-Glover MC, Kraus CL, McKenzie MJ. Body composition, fitness status, and health behaviors upon entering college: an examination of female college students from diverse populations. Clin Med Insights Womens Health. 2016;9(1): 23-29. 